
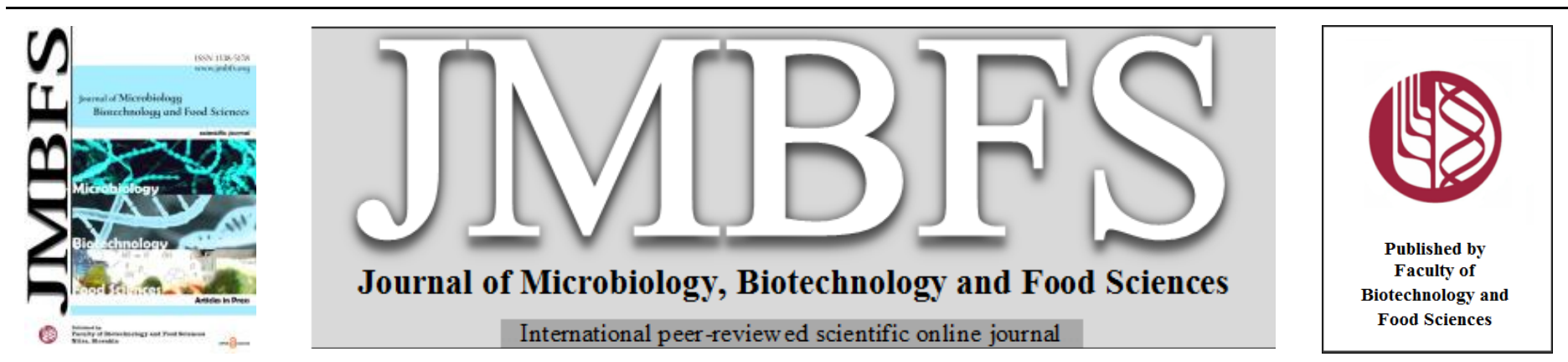

\title{
TAXONOMY AND SPECIES COMPOSITION OF EPIPHYTIC ALGAE IN STA. CRUZ RIVER, LAGUNA (PHILIPPINES)
}

\author{
Eldrin DLR. Arguelles*1, Rosario G. Monsalud ${ }^{1}$
}

\section{Address(es):}

${ }^{1}$ Philippine National Collection of Microorganisms, National Institute of Molecular Biology and Biotechnology (BIOTECH), University of the Philippine Los Baños, College, Laguna, Philippines, 4031.

*Corresponding author: edarguelles@up.edu.ph

\section{ARTICLE INFO}

Received 15. 8. 2019

Revised 7. 8. 2021

Accepted 12.8. 2021

Published 1. 12. 2021

Regular article OPEN OACCESS $_{\text {A }}$

\begin{abstract}
Algal epiphytes attached on three dominant aquatic macrophytes (Pistia striatotes, Eichhornia crassipes and Ipomoea aquatic) were investigated as part of a preliminary study on the ecological assessment of Sta. Cruz River, which has been used primarily for agriculture and fishery. In total, 22 algal taxa were identified on the studied macrophytes: 8 Chlorophyta, 4 Cyanobacteria, 7 Bacillariophyta, and 3 Euglenophyta. The taxa in this paper represent 8 classes, 16 orders, 20 families, 22 genera and 22 species based on the latest algal taxonomical nomenclature. Among these taxa, the existence of a rare filamentous cyanobacteria, Planktothrix compressa (Utermöhl) Anagnostidis et Komárek is described for the first time in the Philippines. A species of diatom is also reported in this study for the first time based on recent algal taxonomic nomenclature and this is Ulnaria ulna (Nitzsch) Compère that is based on the former name of Synedra ulna (Nitzsch) Ehrenberg. These taxonomic records proved that aquatic macrophytes represents a unique habitat for novel and diverse types of algal flora, which demands further investigations in the country.
\end{abstract}

Keywords: Epiphytic algae, macrophytes, Philippines, river, taxonomy

\section{INTRODUCTION}

Macrophytes are aquatic and amphibious plants found in the littoral zones of running waters (eg. rivers, streams, and the like) and shallow lakes contributing largely to the autochthonous carbon pool and oxygen budget of the aquatic ecosystem (Janauer \& Dokulil, 2006). These plants have a significant function in water biocenoses, hydrology and sediment dynamics, biochemical cycles, structuring and altering the physico-chemical features (of an aquatic ecosystem) by photosynthesis, mineralization, and decomposition (Jeppesen et al., 2002; Joniak et al., 2007; Špoljar et al., 2012). Macrophytes have diverse species of microalgae attached to submerged plant parts which have been shown to be an important productive component of the aquatic ecosystem (Sheldon \& Boylen, 1975). Algal epiphytes form a matrix system of microalgae and cyanobacteria attached to submerged aquatic macrophytes. These algae are regarded as primary species in different lotic water systems and are involved in maintaining ecological balance among the different groups of macrophytes and aquatic organisms (Hassan, et al., 2014; Fawzy, 2016). It is widely recognized that these organisms supply food to invertebrates, fish, and in other aquatic fauna in the littoral zone and contributes an estimated of $0.2 \%$ to $41 \%$ of the total primary production in an aquatic ecosystem (Laugaste \& Ruemamen, 2005; Effiong \& Inyang, 2015). Several observational and experimental studies on ecological status of bodies of water showed an increase in the population and diversity of algal epiphytes in response to nutrient loading and pollution (Gil et al., 2006; Peterson et al., 2007; Fawzy, 2016). This led to the consideration of these organisms as excellent bioindicators of environmental and water quality alterations because of its sensitivity to external sources of pollution (Lowe, 1996; Fawzy, 2016). Species of algal epiphytes associated with organically polluted enriched waters include Euglena, Phacus, Nitzschia, Chlorella, Scenedesmus, Chlamydomonas, Cladophora, and Closterium (Effiong \& Inyang, 2015).

The biological interconnection and relationship between algal epiphytes and host aquatic macrophyte in the aquatic environment are still limited and incompletely studied (Wetzel, 1996). Several reports suggested that biotic and abiotic factors such as physico-chemical characteristics of submerged parts (stem, leaves and roots) of macrophytes, availability of substrates, temperature, light intensity and grazing affects the diversity and prevalence of epiphytic algal community (Gil $\boldsymbol{e t}$ al., 2006; Fawzy, 2016). Aquatic macrophytes are sometimes detrimental for algal epiphytes since they are capable of monopolizing light and assimilate nutrients within the vertical expanse of the water column, inhibiting algal epiphytes as well as other submerged macrophytes from acquiring enough resources for growth and survival (Schramm \& Jirka, 1989). Moreover morphology of several macrophyte species, specifically the length of stem and leaves, may limit the growth and proliferation of algal epiphytes by releasing inhibitory substances (allelochemicals) (Tunca et al., 2014). Thus, development of algal epiphyton community as well as its distribution and abundance depend largely on macrophyte host species. On the other hand, in situations where there is an evident increased in algal epiphyte population, it is observed that there is a reduction in the total macrophyte biomass density due to restriction in nutrient diffusion from the water to host plant (Fawzy, 2016). In the Philippines, taxonomic studies of algal epiphytes associated to different macrophytes were done only to those plant species inhabiting Laguna de Bay (Rañola, et al., 1990; Arguelles, 2019 a,b,c; Arguelles, 2020a). To date, a total of 82 taxa of algal epiphytes associated with four dominant aquatic macrophytes (Hydrilla verticilata, Nymphaea pubescens, Eichhornia crassipes and Ipomoea aquatic) found in Laguna de Bay were documented in in the Philippines. These taxonomic surveys reported the occurrence of five rare microalgae - namely, Cryptoglena skujae Marin and Melkonian, Pseudanabaena minima (G.S. An) Anagnostidis, Synechococcus nidulans (Pringsheim) Komárek, Chroococcus schizodermaticus West and Franceia amphitricha (Lagerheim) Hegewald - for the first time in the Philippines. Also, some of the microalgal genera documented in these taxonomic studies (eg. Cryptoglena, Tetradesmus, Nitzschia, Euglena, Chroococcus, Oscillatoria, Phacus and Chlorella) are usually associated with organically polluted enriched waters (Arguelles, 2019 a,b,c; Arguelles, 2020a). These algal epiphytes are regarded as good indicators of environmental changes and water quality due to their sensitivity to external sources of fertilization which can be use in the assessment of ecological status of Laguna de Bay (Arguelles, 2020a) The taxonomic records reported in these studies provided baseline information regarding distribution and diversity of Philippine epiphytic algae from aquatic macrophytes found in local freshwater habitat.

Diversity and ecological studies of epiphytic microalgae of different aquatic macrophytes found in running waters (such as rivers and streams) in the Philippines remain poorly understood. To date, no documented taxonomic survey was conducted on these group of microalgae. Thus, additional taxonomic survey of algal epiphytes of different aquatic macrophytes found in these aquatic ecosystems are needed to deepen our understanding of the diversity and 
ecological roles of these microorganisms. The goal of this investigation is to account the species diversity of algal epiphytes associated to different aquatic macrophytes observed in Sta. Cruz River, one of the 21 major tributary rivers of Laguna de Bay. Also, morphotaxonomic description of each algal taxa were documented together with a brief description of the sampling sites and natural environment of its existence.

\section{MATERIAL AND METHODS}

\section{Study Site}

Sta. Cruz River is considered as one of the main branch rivers of Laguna de Bay. It lies at $14.3001{ }^{\circ} \mathrm{N}$ and $121.4068{ }^{\circ} \mathrm{E}$, specifically within the municipalities of Liliw, Magdalena, Nagcarlan, Pagsanjan, Pila, and Sta. Cruz (Figure 1). The river is measured to be approximately $14.48 \mathrm{~km}$ in length, flowing towards Laguna de Bay. Currently, the principal use of this river is for fishery and agriculture (with coconut and rice production, livestock, poultry, and piggery raising as main activities). This body of water is known to be a receptacle for floodwaters coming from its small tributary rivers such as Maimpis river, Liliw river, San Diego river, Tipacan river, and Talahebeng river (Madamba et al., 1992).

\section{Sampling and Specimen Preparation of Epiphytic Algae}

A single preliminary collection of algal epiphytes from submerged aquatic macrophytes was done from the littoral zone of Sta. Cruz River. The plant parts were put into sterile autoclavable plastics filled with water for laboratory examination. A total of 20 aquatic macrophyte samples (each for Pistia striatotes, Eichhornia crassipes and Ipomoea aquatica) were collected and analyzed throughout the study period. Immediately after collection, these samples were washed several times with sterile distilled water. The algal epiphytes from submerged leaves, stems and roots on the collected aquatic macrophytes were set apart from the plant by gently scraping the attached algae on the plant materia (Zimba \& Hopson, 1997; Arguelles, 2021a,b,c). The collected scraped algal epiphyte was carefully mixed, and a portion of $50 \mathrm{~mL}$ was kept for taxonomic enumeration. The mixed algal epiphyte sample was transferred into a sterile beaker and left overnight to allow settling of the scraped algal samples. An aliquot of $45 \mathrm{~mL}$ of the liquid specimen was removed in the beaker after the settling period. The residual $5 \mathrm{~mL}$ of the collected scraped material was transferred into a sterile drum vial for taxonomic enumeration of algal epiphytes and were preserved using 2-3 drops of Lugol's iodine from the prepared specimens (Utermöhl, 1958; Arguelles et al., 2014; Tunca et al., 2014; Arguelles, 2019a,b,c; Arguelles, 2020b; Arguelles, 2021a,b,c). A small portion $(5 \mathrm{~mL})$ of the concentrated scraped epiphytic algal samples was used for the analysis of diatom flora. The scraped samples were chemically digested following the standard procedure for diatom cleaning and slide preparation of Round et al., (1990). Mixture of cleaned diatoms were dried onto glass coverslips and mounted. Three slides were prepared for each aquatic macrophytes sample for microscopic observation and enumeration of diatoms. The preserved algal specimens and diatom slides were kept as voucher specimens at the Philippine National Collection of Microorganisms, National Institute of Molecular Biology and Biotechnology (BIOTECH), University of the Philippines Los Baños (UPLB), College, Laguna, Philippines.

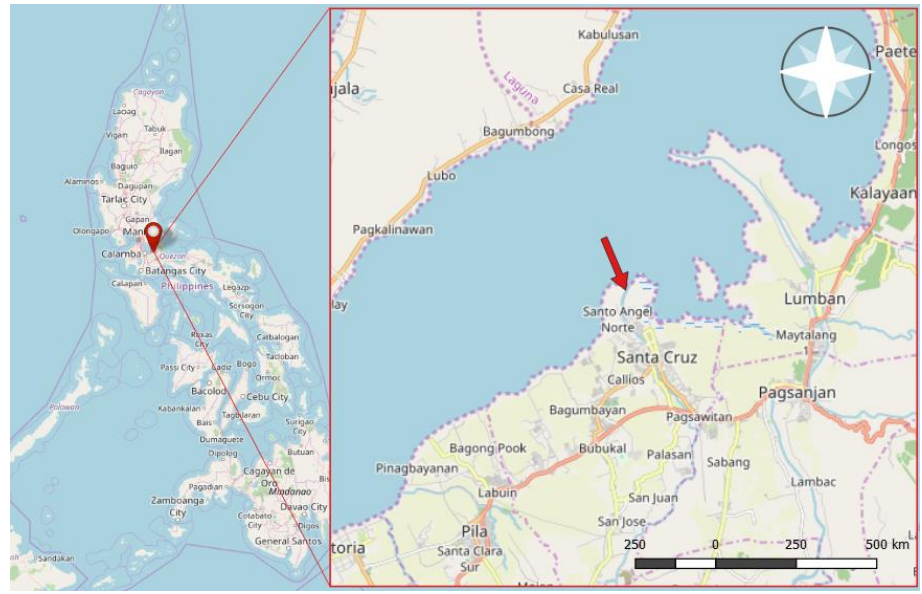

Figure 1 Location map of Sta. Cruz River and its vicinities.

\section{RESULTS AND DISCUSSION}

Epiphytic algal flora of three dominant aquatic macrophyte ( $P$. stratiotes, $E$. crassipes and I. aquatica) observed in Sta. Cruz River consisted of 22 taxa. Of these, 8 belong to the Chlorophyta, 4 to the Cyanobacteria, 7 to the Bacillariophyta, and 3 to the Euglenophyta divisions. Chlorophyta was dominant and comprised $36.36 \%$ of all recorded taxa. Bacillariophyta, Cyanobacteria and Euglenophyta represented $31.81 \%, 18.18 \%$ and $13.63 \%$ of all recorded taxa, respectively. The taxonomic list of the algal epiphytes determined in Sta. Cruz River is given in Table 1. All the taxa are systematically enumerated with morphotaxonomic descriptions along with a simple habitat information where the alga was observed. Illustrative photomicrographs of some of the algal species are given in Plates I-IV. Currently accepted algal taxonomic names were used based on the recent nomenclatural indices for algae of the International Association of Plant Taxonomy (IAPT) and Round et al. (1990).

\section{Dichotomous Key}

1. Cells without membrane-bound organelles ............................... 2

1. Cells with membrane-bound organelles..................................... 5

2. Unicellular and spherical occurring as singly or in clusters of 2 to 4 cells ... Chroococcus minutus

2. Filamentous occurring as single or in groups of trichomes ..................

3. Filamentous cyanobacteria exhibiting true branching Hapalosiphon welwitschii 3. Filamentous cyanobacteria not exhibiting true branching ................. 4

4.Trichomes are straight and 5.0-7.0 $\mu \mathrm{m}$ wide ................. Oscillatoria tenuis 4.Trichomes are straight, cylindrical and $6.0-8.5 \mu \mathrm{m}$ wide Planktothrix compressa

5. Cells with siliceous cell wall.............................................. 6

5. Cells without siliceous cell wall....................................... 12

6. Cells radial in nature

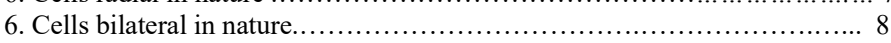

7. Cells grow in linear colonies joined by linking spines... Aulacoseira granulata

7. Cells are not capable of forming linear colonies and without linking spines ...... Cyclotella meneghiniana

8. Cells with sigmoid shape in appearance

8. Cells not sigmoid shape in appearance.................................. 9

9. Cells without raphe system (araphid) Ulnaria ulna

9. Cells with raphe system 10

10. Valves linear not inflated in the median part ...................... Nitzschia palea 10. Valves linear-elliptical and inflated in median part ........................ 11

11. Valves with linear-arched central area Cymbella affinis 11. Valves are linear-elliptical and inflated in median part ..... Rhopalodia gibba

12. Cells with red eyespot and proteinacious pellicle .............................. 13

12. Cells without red eyespot and proteinacious pellicle ......................... 15

13. Protoplast without a rigid lorica

13. Protoplast with a rigid lorica

Trachelomonas armata

14. Cells flattened

Phacus longicauda

14. Cells broadly ellipsoid Leponcinclis acu

15. Cells with stellate chloroplasts .......................... Staurastrum gracile

15. Cells without stellate chloroplasts ............................................ 16

16. Unicellular, solitary or in clump..................................... 19

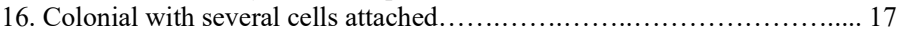

17. Cells are crescent shaped ............................................ 18

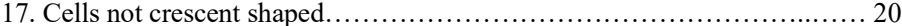

18. Crescent-shaped cells and needle-like in appearance Ankistrodesmus falcatus 18. Crescent-shaped cells and lunate in appearance

Kirchneriella lunaris

19. Cells spherical (10-13 $\mu \mathrm{m}$ in diameter) ................ Chlorococcum infusionum 19. Cells spherical or ellipsoidal $(2-5 \mu \mathrm{m}$ in diameter).......... Chlorella vulgaris

20. Coenobia with spiny projections (terminal cells) ...Scenedesmus quadricauda 20. Coenobia without spiny projections (terminal cells) ...................... 21

21. Coenobia is composed of 16 cells $(100-110 \mu \mathrm{m}$ in diameter) Lacunastrum gracillimum

21. Coenobia is composed of 4-6 cells $(10.0-15.0 \mu \mathrm{m}$ in diameter) Westella botryoides 
Table 1 Distribution of epiphytic algae on dominant aquatic macrophytes from Sta. Cruz River (Laguna, Philippines).

\begin{tabular}{|c|c|c|c|}
\hline \multirow[b]{2}{*}{ Algal Species } & \multicolumn{3}{|c|}{ Dominant Aquatic Macrophytes } \\
\hline & $\begin{array}{c}\text { Water Lettuce } \\
\text { (Pistia stratiotes) }\end{array}$ & $\begin{array}{c}\text { Water Hyacinth } \\
\text { (Eichhornia crassipes) }\end{array}$ & $\begin{array}{c}\text { Water Spinach } \\
\text { (Ipomoea aquatica) }\end{array}$ \\
\hline \multicolumn{4}{|l|}{ Cyanobacteria } \\
\hline \multicolumn{4}{|l|}{ Class Cyanophyceae } \\
\hline \multicolumn{4}{|l|}{ Order: Chroococcales } \\
\hline \multicolumn{4}{|l|}{ Family: Chroococcaceae } \\
\hline Chroococcus minutus (Kützing) Nägeli & + & + & \\
\hline \multicolumn{4}{|l|}{ Order: Oscillatoriales } \\
\hline Oscillatoria tenuis C. Agardh $e x$ Gomont & + & + & \\
\hline \multicolumn{4}{|l|}{ Family: Microcoleaceae } \\
\hline $\begin{array}{l}\text { Planktothrix compressa (Utermöhl) Anagnostidis } \\
\text { et Komárek }\end{array}$ & + & & \\
\hline \multicolumn{4}{|l|}{$\begin{array}{l}\text { Order: Nostocales } \\
\text { Family: Hapalosiphonaceae }\end{array}$} \\
\hline Hapalosiphon welwitschii West \& G.S.West & & & + \\
\hline
\end{tabular}

Mapalosiphon welwitschii West \& G.S.West

Class: Trebouxiophyceae

Order: Chlorellales

Family: Chlorellaceae

Chlorella vulgaris Beyerinck [Beijerinck]

Family: Chlorococcaceae

Chlorococcum infusionum (Schrank) Meneghini $\quad+\quad+$

Family: Hydrodictyaceae

Lacunastrum gracillimum (West \& G.S. West) H.

McManus

Class: Chlorophyceae

Order: Sphaeropleales

Family: Scenedesmaceae

Scenedesmus quadricauda (Turpin) Brébisson $++t_{+}^{+}+$

Westella botryoides (West) De Wildeman +

Order: Sphaeropleales

Family: Selenastraceae

Kirchneriella lunaris (Kirchner) Möbius

Ankistrodesmus falcatus Corda (Ralfs)

Class: Conjugatophyceae (Zygnematophyceae)

Order: Desmidiales

Family: Desmidiaceae

Staurastrum gracile Ralfs ex Ralfs

Bacillariophyta

Class: Bacillariophyceae

Order: Bacillariales

Family: Bacillariaceae

Nitzschia palea (Kützing) W. Smith

Order: Naviculales

Family: Naviculaceae

Gyrosigma acuminatum (Kützing) Rabenhorst

Order: Cymbellales

Family:Cymbellaceae

Cymbella affinis Kützing

Order: Rhopalodiales

Family: Rhophalodiaceae

Rhopalodia gibba (Ehrenberg) O. Müller

Order: Licmophorales

Family: Ulnariaceae

Ulnaria ulna (Nitzsch) Compère

Class: Mediophyceae

Order: Stephanodiscales

Family: Stephanodiscaceae

Cyclotella meneghiniana Kützing

Class: Coscinodiscophyceae

Order: Aulacoseirales

Family: Aulacoseiraceae

Aulacoseira granulata (Ehrenberg) Simonsen

Euglenophyta

Class: Euglenophyceaea

Order: Euglenales

Family: Phacaceae

Phacus longicauda (Ehrenberg) Dujardin

Lepocinclis acus (O.F. Müller) B. Marin and

Melkonian

Family: Euglenaceae

Genus: Trachelomonas Ehrenberg

Trachelomonas armata (Ehrenberg) F. Stein

$+=$ Present

$\begin{array}{ll}+ & + \\ + & +\end{array}$

$+$




\section{Taxonomic Enumeration of Algal Epiphytes}

\section{Cyanobacteria}

Class: Cyanophyceae

Order: Chroococcales

Family: Chroococcaceae

Genus: Chroococcus Nägeli

\section{Chroococcus minutus (Kützing) Nägeli}

\section{BASIONYM: Protococcus minutus Kützing}

Cells spherical or irregularly spherical usually occurring as single or in cluster of 2-4 cells, bluish green to light green in color; colonies enclosed in an amorphous, colorless, homogenous mucilage diffluent at the margin; 5.0-7.0 $\mu \mathrm{m}$ in diameter with sheath and 3.0-5.0 $\mu \mathrm{m}$ in diameter without sheath; protoplast is smooth or slightly granulated.

Found existing as a bluish green or light green layer associated on stems and roots of water lettuce and water hyacinth together with other green microalgae and filamentous cyanobacteria.

Class: Cyanophyceae

Order: Oscillatoriales

Family: Oscillatoriaceae

Genus: Oscillatoria Vaucher ex Gomont

1. Oscillatoria tenuis C. Agardh ex Gomont

Pl. I, Fig. 2

Trichomes usually are scattered and straight $(5.0-7.0 \mu \mathrm{m}$ broad); crosswalls are constricted; terminal cells not attenuated (usually rounded) and lacks calyptra; specialized cells (eg. akinetes and heterocytes) are not present; cells are bluish green in color, 1.0-3.0 $\mu \mathrm{m}$ long and 4.0-5.0 $\mu \mathrm{m}$ wide, granulated protoplasm; terminal cell hemispherical to rounded.

Found existing as greenish to bluish-green layer on leaves and stem of water lettuce and water hyacinth submerged slightly in water together with several filamentous cyanobacteria.

Class: Cyanophyceae

Order: Oscillatoriales

Family: Microcoleaceae

Genus: Planktothrix K. Anagnostidis \& J. Komárek

1. Planktothrix compressa (Utermöhl) Anagnostidis et Komárek

Pl. I, Fig. 3

BASIONYM: Lyngbya compressa Utermöhl 1925

SYNONYM: Oscillatoria compressa (Utermöhl) Geitler 1925

Filaments occurring as planktonic, solitary and without mucilaginous sheaths; trichomes are cylindrical $(6.0-7.5 \mu \mathrm{m}$ wide), dark blue green to brownish in color, cross-walls are slightly constricted and attenuated towards the end without false branching. Cells are shorter than wide and with few aerotopes. Apical cells widely rounded and not capitated. Specialized cell such as heterocytes and akinetes are absent.

\section{A new record for the Philippines.}

Found existing as a bluish-green layer on leaves of water lettuce submerged in water together with several filamentous green algae and cyanobacteria.

Class: Cyanophyceae

Order: Nostocales

Family: Hapalosiphonaceae

Genus: Hapalosiphon Nägeli ex É. Bornet \& C. Flahault

1. Hapalosiphon welwitschii West \& G.S. West

Pl. I, Fig. 4

Cells are elongate and sub-spherical; dark green to bluish green in color, $1.0-2.0 \mu \mathrm{m}$ in length and 2.0-3.0 $\mu \mathrm{m}$ in width, characterized with protoplasm that are smooth, septa of each cell is granulated, terminal end cells usually rounded; trichomes are arranged in one series exhibiting true branches along the filament, anterior end cell is not capitated and attenuated; gelatinous sheaths are colorless and thin; and lateral branches are usually shorter than the main filament.

Found existing as a greenish to blue green layer on stem and leaves of water spinach submerged in water together with other green algae and cyanobacteria.

\section{Bacillariophyta}

Class: Bacillariophyceae

Order: Bacillariales

Family: Bacillariaceae

Genus: Nitzschia Hassall

\section{Nitzschia palea (Kützing) W. Smith}

\section{BASIONYM: Synedra palea Kützing}

Valves are linear lanceolate tapering rapidly at the terminal poles with protracted round to capitate apices. Fibulae with central nodule are discrete and with striae that are slightly visible (18.0-24.0 striae in $10.0 \mu \mathrm{m})$. Valve mantle wider on keel side; $25.0-45.0 \mu \mathrm{m}$ (length) and 4.0-8.0 $\mu \mathrm{m}$ (width), costae is 9.0 $15.0 \mu \mathrm{m}$.

Found existing as a brownish layer on submerged roots and leaves of water hyacinth and water spinach together with other filamentous fungi and diatoms

Class: Bacillariophyceae

Order: Naviculales

Family: Pleurosigmatacea

Genus: Gyrosigma Hassal

\section{Gyrosigma acuminatum (Kützing) Rabenhorst}

BASIONYM: Frustulia acuminata Kützing

Valves are slender and sigmoid in shape with terminal ends that are rounded. The raphe is central and follows an S-shaped appearance. Cells are large $65.0-147.0 \mu \mathrm{m}$ in length and 11.0-20.0 $\mu \mathrm{m}$ in width. Middle area of the cell is oval, not rotated. The cells have two chloroplasts plate-like in appearance. Striae on the valve surface are both parallel and transverse to the raphe.

Found existing as a brownish layer on leaves and stem of water hyacinth and water spinach submerged in water together with cyanobacteria and green algae.
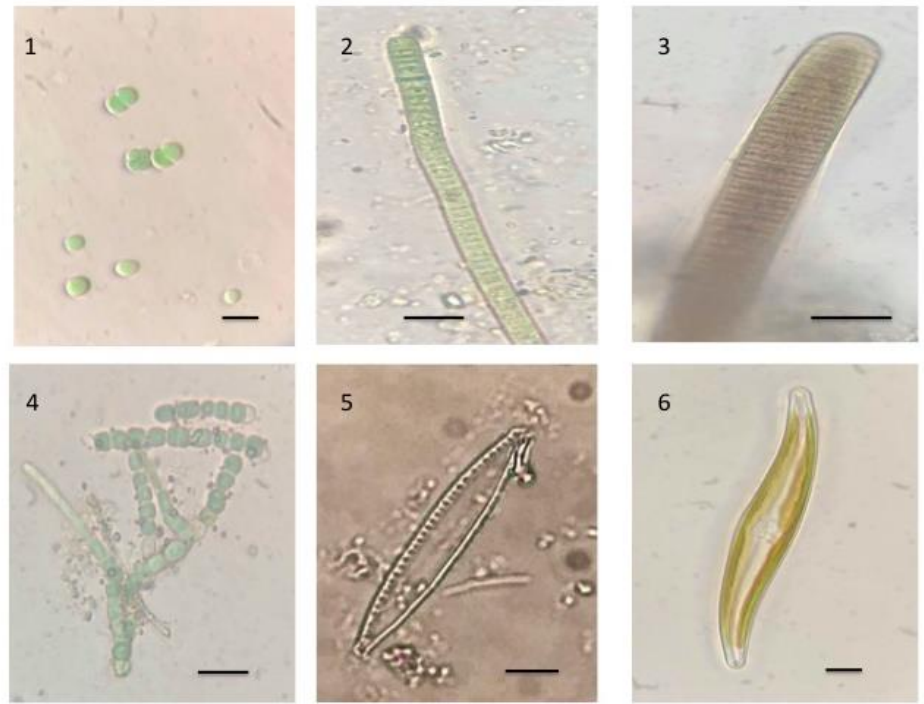

Plate I. Photomicrographs of (1) Chroococcus minutus (Kützing) Nägeli, (2) Oscillatoria tenuis C. Agardh ex Gomont, (3) Planktothrix compressa (Utermöhl) Anagnostidis et Komárek, (4) Hapalosiphon welwitschii West \& G.S.West, (5) Nitzschia palea (Kützing) W. Smith, (6) Gyrosigma acuminatum (Kützing) Rabenhorst. All scale bars $=10 \mu \mathrm{m}$

Class: Bacillariophyceae

Order: Cymbellales

Family: Cymbellaceae

Genus: Cymbella C. Agardh

1. Cymbella affinis Kützing

Pl. II, Fig. 1

Cells are solitary and naviculoid; cell length is $21.5-28.0 \mu \mathrm{m}$ and breadth of $6.0-8.0 \mu \mathrm{m}$. Valves are lanceolate with protracted to slightly subrostrate or subcapitate terminal ends. Cells have narrow axial area and central area that is linear-arched, and indistinct; striae are 8-11 for every $10 \mu \mathrm{m}$.

Found existing as a brownish layer on leaves and stem of water spinach submerged in water together with filamentous fungi and cyanobacteria.

Class: Bacillariophyceae

Order: Rhopalodiales

Family: Rhopalodiaceae

Genus: Rhopalodia O. Müller

\section{Rhopalodia gibba (Ehrenberg) O. Müller}

BASIONYM: Navicula gibba Ehrenberg

Pl. II, Fig. 2

Frustules with swollen middle and are bracket in shape (valve view), apices are sharply bent with convex margin; in girdle view, valves linearelliptical, inflated in median part with rounded poles; valves $45.5-53.5 \mu \mathrm{m}$ long and $11.5-15.0 \mu \mathrm{m}$ broad; ventral margin are usually straight and curve at the ends while the dorsal margin is convex; striae slightly radiate to parallel; striae 14-16 in $10 \mu \mathrm{m}$.

Found existing as a brownish layer on stem and leaves of water hyacinth submerged in water together with several filamentous cyanobacteria and green microalgae.

Class: Bacillariophyceae

Order: Licmophorales 
Family: Ulnariaceae

Genus: Ulnaria (Kutzing) Compère

1. Ulnaria ulna (Nitzsch) Compère

BASIONYM: Bacillaria ulna Nitzsch

Pl. II, Fig. 3

Valves are linear-lanceolate to linear with blunt rostrate to sub-rostrate terminal ends. Cell length is usually 91.0-192.0 $\mu \mathrm{m}$ and width of 4.5-8.5 $\mu \mathrm{m}$. Central area is characterized by having roughly square outline (sometimes circular or elliptical outline) extending to the margin of the valves. Ghost striae are noticeable within the central area of the cell. Striae are parallel and usually 7 9 for every $10 \mu \mathrm{m}$.

Found existing as a brownish layer on stems and leaves of water lettuce submerged in water together with other unicellular and filamentous fungi as well as cyanobacteria.

Class: Coscinodiscophyceae

Order: Aulacoseirales

Family: Aulacoseiraceae

Genus: Aulacoseira Thwaites

\section{Aulacoseira granulata (Ehrenberg) Simonsen}

PI. II, Fig. 4

BASIONYM: Gaillonella granulata Ehrenberg

Frustules are cylindrical, joined together forming filamentous type of colonies. Valves are 5.0-17.0 $\mu \mathrm{m}$ in diameter, with height of the mantle of 4.0 $21.0 \mu \mathrm{m}$. The ratio of the height of the mantle to diameter of the valve is greater than 0.9 and lower than 5 . The mantle is characterized by having sides that are straight and valve face that is flat. Linking spines are triangular and short and located at the end of each pervalvar costa.

Found existing as a brownish layer on leaves of water spinach submerged in water together with other green microalgae and filamentous cyanobacteria.

Class: Mediophyceae

Order: Thalassiosirales

Family: Stephanodiscaceae

Genus: Cyclotella (Kützing) Brébisson

1. Cyclotella meneghiniana Kützing

Pl. II, Fig. 5

Cells rounded with central and marginal areas. Valves are small and disc-shaped with a narrow mantle; cells 8.0-19.0 $\mu \mathrm{m}$ in diameter characterized by having marginal chambered striae with flat and smooth central area covering $1 / 3$ of the valve surface.

Found existing as a brownish layer on stem and leaves of water lettuce and water spinach slightly submerged in water together with diatoms, green microalgae, and filamentous cyanobacteria.

\section{Chlorophyta}

Class: Chlorophyceae

Order: Sphaeropleales

Family: Selenastraceae

Genus: Kirchneriella Schmidle

\section{Kirchneriella lunaris (Kirchner) Möbius $\quad$ Pl. II, Fig. 6 \\ BASIONYM: Rhapidium convolatum var. lunare Kirchner} Kirchneriella lunata Schmidle

Thallus is microscopic and colonial (cells are seldom solitary); clusters of 2-4-8 up to 64 crescent-shaped cells within a mucilaginous sheath Cells are lunate, cylindrical, or sickle-shaped, 3.0-4.0 x 2.0-8.0 $\mu \mathrm{m}$ (length $\mathrm{x}$ width). Cells with single parietal chloroplast adjacent at the margin of the cell with $1-4$ pyrenoids per cell.

Found existing as a light greenish layer on stem and leaves of water hyacinth and water lettuce submerged in water together with other filamentous cyanobacteria.

Class: Chlorophyceae

Order: Sphaeropleales

Family: Selenastraceae

Genus: Ankistrodesmus Corda

1. Ankistrodesmus falcatus Corda (Ralfs)

BASIONYM: Micrasterias falcatus Corda

Pl. III, Fig. 1

Cells are solitary or sometimes in clustered bundles or in tufts or mixed with other microscopic algae, lacking a mucilage envelope, cells are crescent-shaped and needle-like in appearance; $21.0-33.0 \mu \mathrm{m}$ in length and 2.0 $4.0 \mu \mathrm{m}$ in width; narrowly tapering toward the anterior and posterior end, sometimes straight but majority of the times occurring as curved rods; parietal chloroplast with pyrenoid.

Found existing as a dark greenish layer on stem and leaves of water lettuce and water hyacinth submerged in water together with filamentous fungi and cyanobacteria.
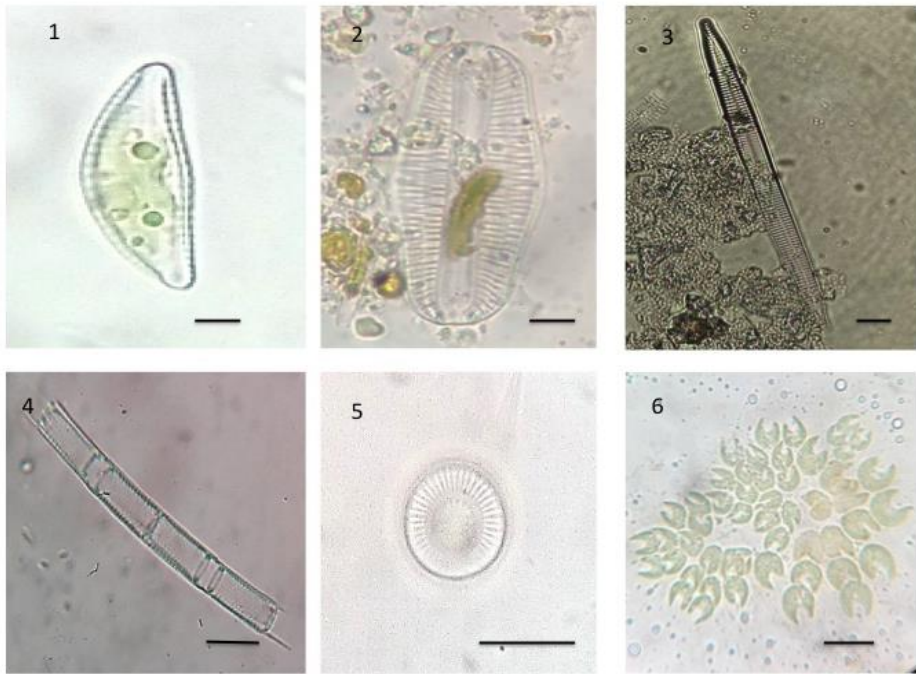

5

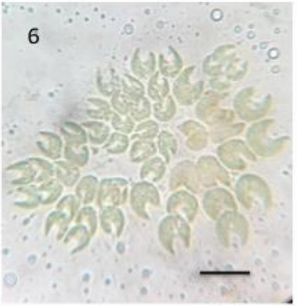

Plate II. Photomicrographs of (1) Cymbella affinis Kützing, (2) Rhopalodia gibba (Ehrenberg) O. Müller, (3) Ulnaria ulna (Nitzsch) Compère, (4) Aulacoseira granulata (Ehrenberg) Simonsen, (5) Cyclotella meneghiniana Kützing, (6) Kirchneriella lunaris (Kirchner) Möbius. All scale bars $=10 \mu \mathrm{m}$.

Class: Chlorophyceae

Order: Sphaeropleales

Family: Scenedesmaceae

Genus: Scenedesmus Meyen

1. Scenedesmus quadricauda Chodat

BASIONYM: Achnanthes quadricauda Turpin

Pl. III, Fig. 2

Cells oblong to spherical in shape (5.0-6.0 $\mu \mathrm{m}$ in length and 1.0-3.0 $\mu \mathrm{m}$ in width); parietal chloroplasts are present with a solitary pyrenoid; cells usually occur in parallel attached adjacent to each other (organized linearly in groups); inner cells of the coenobium are usually without spines while the terminal cells with two spiny projections.

Found existing as a light greenish layer on stems of water spinach and water lettuce submerged in water together with other filamentous cyanobacteria.

Class: Chlorophyceae

Order: Sphaeropleales

Family: Scenedesmaceae

Genus: Westella Meyen

\section{Westella botryoides (West) De Wildeman}

BASIONYM: Tetracoccus botryoides West

PI. III, Fig. 3

Colonies occurring usually in 4-6 celled coenobia (10.0-15.0 $\mu \mathrm{m}$ in diameter). Cells spherical but are flat and are in contact with other cells in the colony, 3.0-8.0.0 $\mu \mathrm{m}$ in diameter, with smooth cell walls. Cells are uninucleated with single parietal chloroplast and a pyrenoid. Usually assemble to form irregular colonies (compound colonies to over 100 cells with $90.0-110.0 \mu \mathrm{m}$ in diameter)

Found existing as a brownish to greenish layer on leaves of water hyacinth submerged slightly in water together with several cyanobacteria.

Class: Trebouxiophyceae

Order: Chlorellales

Family: Chlorellaceae

Genus: Chlorella Beyerinck [Beijerinck]

1. Chlorella vulgaris Beyerinck [Beijerinck]

BASIONYM: Chlorella pyrenoidosa var. duplex (Kützing)

Cells are 2.0-5.0 $\mu \mathrm{m}$ in diameter, symmetrical; chloroplast bandshaped or lobed; pyrenoid is solitary associated with starch grains; cell reproduction is by formation of autospores released by rupture from the mother cell wall.

Found existing as a brownish to greenish layer on stem and leaves of water spinach submerged slightly in water together with other filamentous fungi and cyanobacteria.

Class: Trebouxiophyceae

Order: Chlorellales

Family: Chlorococcaceae

Genus: Chlorococcum Meneghini

1. Chlorococcum infusionum (Schrank) Meneghini Pl. III, Fig. 5

SYNONYM: Chlorococcum humicola (Nägeli) Rabenhorst 1868

BASIONYM: Cystococcus humicola Nägeli

Spherical cells with a diameter of $10.0-13.0 \mu \mathrm{m}$, solitary but sometimes several cells form a cluster of greenish cells, parietal chloroplasts with a single pyrenoid covering the cells. 
Found existing as a light greenish layer on stem and leaves of water hyacinth and water spinach submerged in water together with several filamentous blue green algae.

\section{Class: Trebouxiophyceae}

Order: Chlorellales

Family: Hydrodictyaceae

Genus: Lacunastrum H. McManus

1. Lacunastrum gracillimum (West \& G.S. West) H. McManus Pl. III, Fig. 6

BASIONYM: Pediastrum duplex var. gracillimum (Kützing)

Coenobia is composed of 8.0-16.0 cells (100.0-110.0 $\mu \mathrm{m}$ in diameter); marginal cells are morphologically similar or with two processes that are hornlike in appearance. Cell walls are characterized as smooth. Marginal cells of the coenobium are 16.0 - $21.0 \mu \mathrm{m}$ long, $14.0-18.0 \mu \mathrm{m}$ in diameter; inner cells 13.0 $19.0 \mu \mathrm{m}$ long, $16.0-22.0 \mu \mathrm{m}$ in diameter.

Found existing as a greenish layer on stem and leaves of water hyacinth submerged in water together with other filamentous green algae and cyanobacteria.
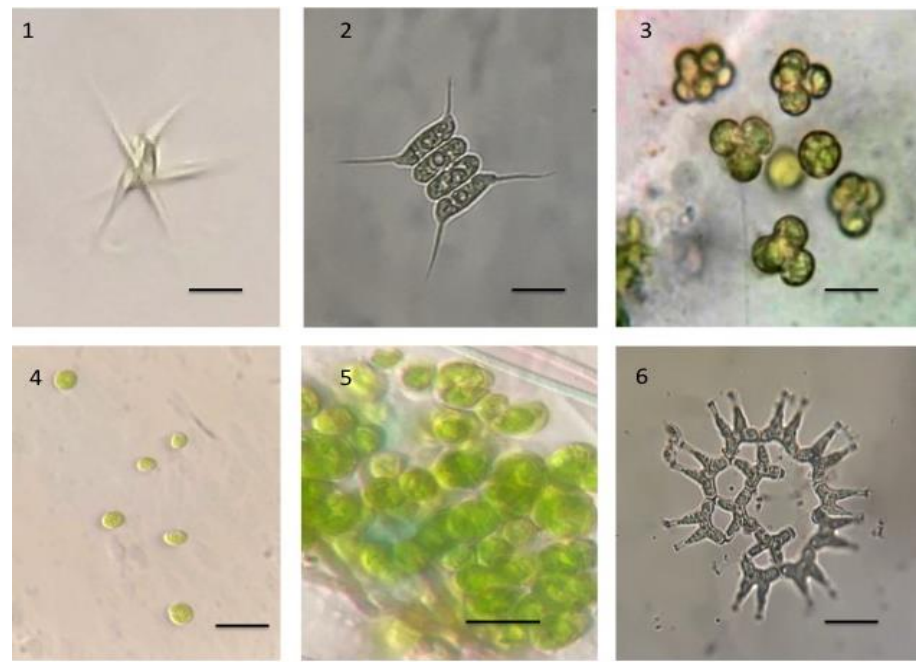

Plate III. Photomicrographs of (1) Ankistrodesmus falcatus Corda (Ralfs), (2) Scenedesmus quadricauda Chodat, (3) Westella botryoides (West) De Wildeman, (4) Chlorella vulgaris Beyerinck [Beijerinck], (5) Chlorococcum infusionum (Schrank) Meneghini, (6) Lacunastrum gracillimum (West \& G.S. West) H. McManus. All scale bars $=10 \mu \mathrm{m}$.

Class: Conjugatophyceae (Zygnematophyceae)

Order: Desmidiales

Family: Desmidiaceae

Genus: Staurastrum Meyen ex Ralfs

1. Staurastrum gracile Ralfs ex Ralfs

Pl. IV, Fig. 1

Cells are small to large with 13.0-54.0 $\mu \mathrm{m}$ in length and 21.0-107.0 $\mu \mathrm{m}$ in width; shallow median constriction (isthmus) is present where semicell walls overlap, usually occurring in two intergrading cell morphologies. Single stellate (lobed) chloroplasts (end view), with one or several pyrenoid Reproduction is by cell division and formation of semicell typical of desmids.

Found existing as a light greenish layer on leaves and stem of water hyacinth submerged slightly in water together with other diatoms, green algae, and filamentous cyanobacteria.

\section{Euglenophyta}

Class: Euglenophyceaea

Order: Euglenales

Family: Phacaceae

Genus: Phacus Dujardin

1. Phacus longicauda (Ehrenberg) Dujardin

BASIONYM: Euglena longicauda Ehrenberg

Pl. IV, Fig. 2

Cells are solitary, elliptic and broadly flattened $(71.5 \mu \mathrm{m} \times 43.5 \mu \mathrm{m})$ anterior end is broadly rounded while the terminal end are tapering into a long cauda (nearly straight or slightly curved usually 20.0 - $25.0 \mu \mathrm{m}$ long); numerous small discoid chloroplasts; single paramylon grain lies at the center; spirally striated pellicle; eyespot is present.

Found existing as a light greenish layer on stems and leaves of water spinach submerged slightly in water together with other cyanobacteria.

Class: Euglenophyceaea

Order: Euglenales

Family: Phacaceae

Genus: Lepocinclis Perty

\section{Lepocinclis acus (O.F. Müller) B. Marin and Melkonian}

PI. IV, Fig. 3

BASIONYM: Vibrio acus O.F. Mülle

Cells are elongated and spindle-shaped characterized by having a pointed anterior and posterior end; $59.3 \mu \mathrm{m} \times 16.5 \mu \mathrm{m}$; posterior end about 11.0 $\mu \mathrm{m}$ long; two big and elongated rod-shaped paramylon bodies and numerous disc-shaped chloroplasts are distributed within the cell.

Found existing as a light greenish layer on leaves and stems of water spinach and water hyacinth submerged slightly in water together with other filamentous green algae and cyanobacteria.

Class: Euglenophyceaea

Order: Euglenales

Family: Euglenaceae

Genus: Trachelomonas Ehrenberg

1. Trachelomonas armata (Ehrenberg) F. Stein

BASIONYM: Pantotrichum armatum Ehrenberg

Pl. IV, Fig. 4

Cells are always solitary, and protoplasts are highly metabolic and are loosely enclosed in a firm gelatinous shell (lorica). Lorica broadly ovoid, (27.4 $\mu \mathrm{m} \times 23.0 \mu \mathrm{m})$; presence of (4-6) spines at the posterior end of the cell; apical pore of the cell encircled with low collar; parietal chloroplasts which may or may not have pyrenoids; single emergent flagellum can be observed in an aperture.

Found existing as a brownish to greenish layer on stem and leaves of water lettuce submerged slightly in water together with other filamentous fung and cyanobacteria.
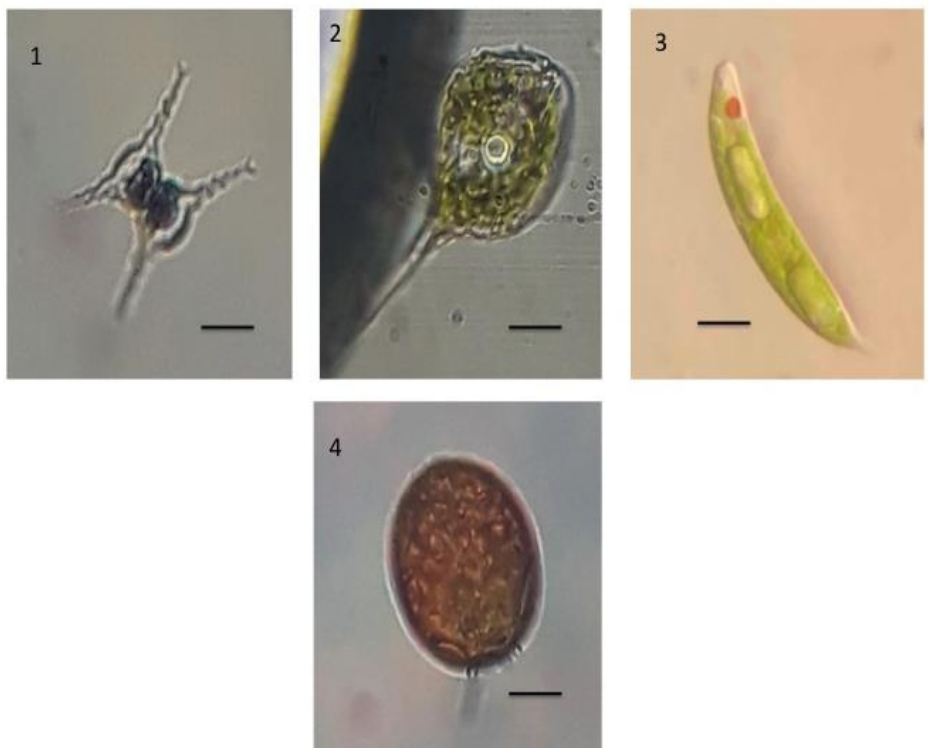

Plate IV. Photomicrographs of (1) Staurastrum gracile Ralfs ex Ralfs, (2) Phacus longicauda (Ehrenberg) Dujardin, (3) Lepocinclis acus (O.F. Müller) B Marin and Melkonian, (4) Trachelomonas armata (Ehrenberg) F. Stein. All scale bars $=10 \mu \mathrm{m}$

In the Philippines, little is known on the distribution, taxonomy and diversity of cyanobacteria and microalgae associated with aquatic macrophytes found in marine and freshwater ecosystems. A total of 22 epiphytic algal taxa from three dominant aquatic macrophyte (Pistia stratiotes, Eichhornia crassipes and Ipomoea aquatica) found in Sta. Cruz River were observed in the study. The taxonomic list present 8 taxa belonging to the Chlorophyta, 4 to the Cyanobacteria, 7 to the Bacillariophyta, and 3 taxa to the division Euglenophyta. This study reported and described for the first time in the Philippines the existence of Planktothrix compressa (Utermöhl) Anagnostidis et Komárek, a rare cyanobacteria first reported in submerged roots of Pistia stratiotes found in Sta Cruz River. One species is also reported here for the first time in the Philippines based on recent algal taxonomic nomenclature and this is Ulnaria ulna (Nitzsch) Compère that is based on the former name of Synedra ulna (Nitzsch) Ehrenberg. In general, it was observed that the consortium of algal mats in submerged stem, leaves and roots of the dominant macrophytes are composed mainly of unicellular and filamentous type of the eukaryotic algae and cyanobacteria as well as other filamentous fungi. The algal groups observed on the macrophytes have been recorded to be similar in other taxonomic studies done for macrophytes in aquatic ecosystems found in the Philippines and other countries (Rañola et al., 1990; Sultana et al., 2004; Arguelles, 2019 a, b). Algal epiphytes associated with a macrophyte, Vallisneria americana in St. John Rivers in Florida (USA) documented a total of 122 taxa of algal epiphytes wherein thirteen genera (Cyclotella, Nitzschia, Synedra (Ulnaria), Rhopalodia Ankistrodemus, Lacunastrum (Pediastrum), Chroococcus, Oscillatoria, Chlorococcum, Scenedesmus, Chlorella, Euglena and Trachelomonas) were observed to be similar to the taxa reported on the current investigation (Dunn et 
al., 2008). Also, taxonomic survey on the composition of algal epiphytes from three aquatic macrophytes (Typha latifolia, Nymphaea alba, and Ceratophyllum demersum,) at Acarlal floodplain forest in Northern Turkey reported the occurrence of similar algal taxa such as Phacus longicauda, Trachelomonas armata, Cyclotella meneghiniana, Nitzschia palea, Rhopalodia gibba, and Chroococcus minutus (Tunca et al., 2014). In running water environment, submerged aquatic macrophytes contribute to oxygen pool and are considered important habitats for several aquatic organisms (microbes as well small invertebrates and vertebrates). Macrophytes are abundant in the littoral zones of rivers worldwide, frequently considered as dominant species in the periphyton communities and sometimes associated in producing nuisance growths under eutrophic conditions. The environmental persistence of these organisms in an aquatic environment promotes the occurrence of high taxonomic diversity of cyanobacterial and microalgal epiphytes that can be use as good ecological indicators to determine the quality of water in a river system. In this study, several algal taxa were identified which can be use as biological indicator for aquatic ecosystem health assessment of Sta. Cruz River. Some of the algal taxa identified such as Aulacoseira granulata, Cyclotella meneghiniana, Nitzschia palea, Phacus longicauda, Lepocinclis acus, Trachelomonas armata, Oscillatoria tenuis, Planktothrix compressa, Chroococcus minutus, Scenedesmus quadricauda, and Chlorella vulgaris are indicative of nutrient pollution in a eutrophic system (Dunn et al., 2008; Effiong \& Inyang, 2015; Arguelles, 2020a). The taxonomic data obtained on this survey will serve as baseline data in the evaluation of the current ecological status of Sta. Cruz River. Also, evaluation of the interaction of other environmental parameters (such as dissolved oxygen, $\mathrm{pH}$, light intensity, and temperature) in relation to the spatial-tempora distribution of algal epiphytes in Sta. Cruz River is important to further understand the ecological state of the river.

\section{CONCLUSION}

The taxonomic survey done in this study shows diverse collection of microalgae and cyanobacteria associated with aquatic macrophytes found in Philippine freshwater ecosystem. Among these taxa, the existence of a rare filamentous cyanobacteria, Planktothrix compressa (Utermöhl) Anagnostidis et Komárek is described for the first time in the Philippines. The result of this survey suggests that further study on the diversity and ecological interactions of algal epiphytes in relation to other aquatic macrophytes found in both marine and freshwater habitat is needed since only few studies were reported in the Philippines. Also, the use of combined morphological and molecular techniques for future taxonomic studies of epiphytic algae in the Philippines is recommended. The current survey provided a quick assessment of some of the dominant algal epiphytes in a river ecosystem and provides basal information for further molecular studies.

Acknowledgments: The authors are thankful to the National Institute of Molecular Biology and Biotechnology (BIOTECH), University of the Philippines Los Baños for the financial support of the study.

\section{REFERENCES}

Arguelles, E.D.L.R. (2021a). Phytotelm algae of Pandan [Pandanus amaryllifolius Roxb.] (Pandanaceae) leaf axil tanks from Laguna (Philippines). Tropical Natural History, 21(1), 167-183.

Arguelles, E.D.L.R. (2021b). Unseen microalgal diversity - phytotelmata in Neoregelia spp. L.B. Smith (Bromeliaceae) from florists wholesalers in Laguna, Philippines. Philippine Journal of Science, 150(1), 123-137.

Arguelles, E.D.L.R. (2021c). First taxonomic records of epizoic freshwater algae on Golden apple snails (Pomacea canaliculata Lamarck) from rice paddies in Laguna (Philippines). Philippine Journal of Science, 150(4), 829-844.

Arguelles, E.D.L.R. (2020a). Species composition of algal epiphyton of Pink Lotus (Nymphaea pubescens Willd) found in Laguna de Bay (Philippines). Walailak Journal of Science and Technology, 17(3), 237-256. https://doi.org/10.48048/wjst.2020.5015

Arguelles, E.D.L.R. (2020b). Microalgae of pineapple [Ananas comosus (L.) Merr] phytotelmata from Calauan, Laguna (Philippines). Philippine Journal of Science, 149(3), 589-602.

Arguelles, E.D.L.R. (2019a). Morphotaxonomic study of algal epiphytes from Ipomoea aquatica Forssk. (Convolvulaceae) found in Laguna de Bay (Philippines). Pertanika Journal of Tropical Agricultural Science, 42(2), 817 832.

Arguelles, E.D.L.R. (2019b). Systematic study of some epiphytic algae (nondiatoms) on the submerged parts of water hyacinth [Eichhornia crassipes (Mart.) Solms-Loubach] found in Laguna de Bay, Philippines. Tropical Life Sciences Research, 30(1), 1-21. https://doi.org/10.21315/t1sr2019.30.1.1

Arguelles, E.D.L.R. (2019c). Descriptive study of some epiphytic algae growing on Hydrilla verticillata (L.f) Royle (Hydrocharitaceae) found in the shallow freshwater lake, Laguna de Bay (Philippines). Egyptian Journal of Aquatic Biology and Fisheries, 23(2), 15-28. https://doi.org/10.21608/ejabf.2019.29300

Arguelles, E.D.L.R., \& Monsalud, R.G. (2017). Morphotaxonomy and diversity of terrestrial microalgae and cyanobacteria in biological crusts of soil from paddy fields of Los Baños, Laguna (Philippines). Philippine Journal of Systematic Biology, 11(2), 25-36. https://doi.org/10.26757/pjsb.2017b11016

Arguelles, E.D.L.R. (2016). Morphotaxonomic account of epilithic microalgae and cyanobacteria in Los Baños, Laguna (Philippines). IAMURE International Journal of Ecology and Conservation, 17, 22-39. https://doi.org/10.7718/ijec.v17i1.1061

Arguelles, E.D.L.R., Martinez-Goss, M.R., \& SHIN, W. (2014). Some noteworthy photosynthetic euglenophytes from Laguna and vicinities. The Philippine Scientist, 51, 1-36.

Desikachary, T. V. (1959). Cyanophyta. I.C.A.R. monograph on Algae.

Dunn, A.E., Dobberfuhl, D.R., \& Casamatta, D.A. (2008). A survey of algal epiphytes from Vallisneria americana Michx. (Hydrocharitaceae) in the Lower St. Johns River, Florida. Southeastern Naturalist, 7(2), 229-244. https://doi.org/10.1656/1528-7092(2008)7[229:asoaef]2.0.co;2

Effiong, K.S., \& INYANG, A.I. (2015). Epiphyton algae on aquatic macrophyte (water hyacinth) in a tropical lagoon and their possible use as indcator International Journal of Environmental Monitoring and Analysis, 3(6), 404-410. https://doi.org/10.11648/j.ijema.20150306.14

Fawzy, M.A. (2016). Spatial distribution of epiphytic algae growing on the aquatic macrophytes Phragmites australis and Echinochloa stagnina at AssiutEgypt. Minia Science Bulletin Botany Section, 27(2), 1-26.

Gil, M., Armitage, A.R., \& Fourqurean, J.W. (2006). Nutrient impacts on epifaunal density and species composition in a subtropical seagrass bed Hydrobiologia, 569, 437-447. https://doi.org/10.1007/s10750-006-0147-7

International Association of Plant Taxonomy (Taxon-IAPT). (2020). Nomenclatural Indices and Repositories. https://www.iaptglobal.org/indices-andrepositories.

Hassan, F.M., Salman, J.M., Alkam, F.A., \& Jawad, H.J. (2014). Ecological observations on epipelic algae in Euphrates River at Hindiya and Manathira, Iraq. International Journal of Advance Research, 2, 1183-1194.

Janauer, G.A., \& Dokulil, M. (2006). Macrophytes and algae in running waters In: G. Ziglio, M., Siligardi, \& G. Flaim (Eds.). Biological Monitoring of Rivers, Chichester (pp. 89-109) John Wiley and Sons https://doi.org/10.1002/0470863781.ch6

Jeppesen, E., Søndergaard, M., Søndergaard, M., Christoffersen, K., TheilNielsen, J., \& Jürgens, K. (2002). Cascading trophic interactions in the littoral zone: an enclosure experiment in shallow Lake Stigsholm, Denmark. Fundamental and Applied Limnology - Archiv für Hydrobiologie, 153, 533-555. https://dx.doi.org/10.1127/archiv-hydrobiol/153/2002/533

John, D.M., Tsarenko, P.M. (2011). Order Chlorococcales, In: D.M. John, B.A Whitton, \& A.J. Brook, (Eds.). The freshwater algal flora of the British Isles. An identification guide to freshwater and terrestrial algae (pp. 327-409). Cambridge University Press.

Joniak, T., Kuczyńska-Kippen, N., \& Nagengast, B. (2007). The role of aquatic macrophytes in microhabitual transformation of physical-chemical features of small water bodies. Hydrobiologia, 584, 101-109. https://doi.org/10.1007/s10750-007-0595-8

Klaassen, M., \& Nolet, B.A. (2007). The role of herbivorous water birds in aquatic systems through interactions with aquatic macrophytes, with special reference to the Bewick's Swan - Fennel Pondweed system. Hydrobiologia, 584: 205-213. https://doi.org/10.1007/s10750-007-0598-5

Komárek, J., \& Anagnostidis, K. (2005). Cyanoprokaryota, II. Teil Oscillatoriales, Band 19/2, Süßwasserflora von Mitteleuropa. Elsevier.

Laugaste, R., \& Ruemamen, M. (2005). The composition and density of epiphyton in some macrophyte species in the partly meromictic Lake Verevi. Hydrobiologia, 547(5), 137-150. https://doi.org/10.1007/s10750-005-4155-9

Lowe, R.L. (1996). Periphyton partterns in lakes. In: R.J. Stevenson, M.L. Bothwell, \& R.L. Lowe (Eds.). Algal Ecology. Freshwater Benthic Ecosystems. (pp. 57-76) Academic Press. https://doi.org/10.1016/b978-012668450-6/50032-1 Madamba, L.S.P., Galapate, R.P., Decena, A.M., \& Casunuran, V.P. (1992) Pollution load contribution of Sta. Cruz River to Laguna de Bay. Philippine Journal of Science, 121(2), 161-180.

Martinez, M.R. (1984). A checklist of blue-green algae of the Philippines National Institute of Molecular Biology and Biotechnology (BIOTECH)University of the Philippines Los Baños.

McGregor, G., Fabbro, L.D., \& Lobegeiger, J.S. (2007). Freshwater planktic Chroococcales (Cyanoprokaryota) from North-Eastern Australia: a morphological evaluation. Nova Hedwigia, 84(3/4): 299-331. https://dx.doi.org/10.1127/0029-5035/2007/0084-0299

Mollenhauer, D., Büdel, B., \& Mollenhauer, R. (1994). Approaches to species delimitations in the genus Nostoc Vaucher 1803 ex Bornet et Flahault 1888 Algological Studies, 75, 189-209. https://doi.org/10.1127/algol_stud/75/1995/189 Peterson, B.J., Frankovich, T.A., \& Zieman, J.C. (2007). Response of seagrass epiphyte loading to field manipulations of fertilization, gastropod grazing and leaf turnover rates. Journal of Experimental Marine Biology and Ecology, 349, 61-72. https://doi.org/10.1016/j.jembe.2007.04.012

Prescott, G.W. (1962). Algae of the western great lakes area, Dubuque, Iowa, Wm. C. Brown Co. Publishers. 
Rañola, M.C.G., Zafaralla, M.T., \& Valmonte, R.A.D. (1990). A preliminary investigation on the epiphyton of Eichhornia crassipes (Mart.) Solm. roots in Laguna de Bay. UP Los Baños Journal, 1(1), 53-67.

Round, F.E., Crawford, R.M., \& Mann, D.G. (1990). The Diatoms: Morphology and Biology of the Genera. Cambridge: Cambridge University Press. https://doi.org/10.1017/s0025315400059245

Santos-Borja, A., \& Nepomuceno, D.N. (2003). Experience and Lessons learned brief for Laguna de Bay, Philippines [Paper Presentation], Lake Basin Management Initiative ILEC/LakeNet Regional Workshop for Asia: Sharing Experience and Lessons Learned in Lake Basin Management, Manila, Philippines.

Schramm, H.L., \& Jirka, K.J. (1989). Epiphytic macroinvertebrates as a food resource for bluegills in Florida lakes. Transactions of the American Fisheries Society, 118, 416-426. https://doi.org/10.1577/1548 8659(1989)118\%3C0416:EMAAFR\%3E2.3.CO;2

Sheldon, R.B., \& Boylen, C.W. (1975). Factors affecting the contribution by epiphytic algae to the primary productivity of an oligotrophic freshwater lake. Applied Microbiology, 30(4), 657-667. https://doi.org/10.1128/am.30.4.657667.1975

Špoljar, M., Fressl, J., Dražina, T., Meseljević, M., \& Grčić, Z. (2012). Epiphytic metazoans on emergent macrophytes in oxbow lakes of the Krapina River, Croatia: differences related to plant species and limnological conditions. Acta Botanica Croatia, 71(1), 125-138. https://doi.org/10.2478/v10184-011-0062-5

Sultana, M., Asaeda, T., Manatunge, J., \& Ablimit, A. (2004). Colonisation and growth of epiphytic algal communities on Potamogeton perfoliatus under two different light regimes. New Zealand Journal of Marine and Freshwater Research, 38, 585-594. https://doi.org/10.1080/00288330.2004.9517264

Tunca, H., Ongun Sevindik, T., Nur Bal, D., \& Arabaci, S. (2014). Community structure of epiphytic algae on three different macrophytes at Acarlar floodplain forest (northern Turkey). Chinese Journal of Oceanology and Limnology, 32(4), 847-857. https://doi.org/10.1007/s00343-014-3205-4

Utermöhl, H. (1958). Zur Vervollkommnung der quantitativen Phytoplankton Methodik. Mitteilung Internationale Vereinigung fuer Theoretische und $\begin{array}{llll}\text { Amgewandte. } & \text { Limnologie, } & \text { 9, } & \text { 1-38 }\end{array}$ https://doi.org/10.1080/05384680.1958.11904091

Velasquez, G.T. (1962). The blue green-algae of the Philippines. Philippine Journal of Science, 91(3), 267-380.

Wetzel, R.W. (1996). Benthic algae and nutrient cycling in lentic freshwater ecosystem. In: R.J. Stevenson, M.L. Bothwell, \& R.L. Lowe (Eds.). Algal Ecology: freshwater benthic ecosystem. (pp. 641-667) Academic Press. https://doi.org/10.1016/b978-012668450-6/50049-7

Whitton, B.A. (2011). Phylum Cyanobacteria (Cyanophyta). In: D.M. John, B.A Whitton, and A.J. Brook (Eds.). The freshwater algal flora of the British Isles. An identification guide to freshwater and terrestrial algae. (pp. 31-158). Cambridge University Press.

Zafaralla, M.T. (1998). Microalgae of Taal Lake. Bicutan, Taguig, Metro Manila. National Academy of Science and Technology.

Zimba, P.V., \& Hopson, M.S. (1997). Quantification of epiphyte removal efficiency from submersed aquatic plants. Aquatic Botany, 58(2), 173-179. https://doi.org/10.1016/S0304-3770(97)00002-8 